\title{
レッドデータブックの出版と有効活用
}

\section{Publication and Effective Use of Red Data Book}

井上 健 ${ }^{*}$

Ken Inoue

はじめに

自然環境の改变に伴い, 多くの動植物が絶滅したり, 絶 滅危惧の状態になっている。これ以上の絶滅を防ぐために は，どんな種類に絶滅の懼れがあり，また，どのような要 因が絶滅に関与しているのか知ることが必要である。ある 地域における絶滅の危惧にある動植物をリストアップし， どの程度の絶滅リスクがあり, どのような要因が絶滅リス クをむたらしているか, 現在の分布情報や個体数の情報, 近縁の種類との識別点などをまとめたのがレッドデータブッ クである。レッドデータブックは哺乳類・鳥類・両生爬虫 類・植物など分類群ごとにまとめられるのが普通であり, また, 取り扱う地域は地球全体加ら国単位, 市町村単位之 いろいろな単位のものが出版されている。発行主体も環境 省や県などの行政機関，IUCN (国際自然保護連合)のよ うな大規模な自然保護団体，分類学研究者を中心にした市 民団体など様々である。

動植物のこれ以上の状況の悪化を阻止したり，危機的状 況に陥った動植物の個体群の自生地における再生プランの 作成のための基礎デー夕を提供するのがレッドデータブッ ク作成の目的である。筆者は植物分類学を専門にしてお り, 2000 年発行の環境庁版植物版レッドデータブック作 成に携わってきた。この経験を基にレッドデータブック作 成の過程を检証し，作成されたレッドデータブックの有効 活用, 問題点などについて考えていきたい。

\section{1. 植物版レッドデータブックの作成}

レッドデータブックでは絶滅危惧生物のリストをつくり, それぞれの種について絶滅危惧の程度を評価する必要があ る。リストを作るためには，その地域の動物相や植物相が 前もって判っていることが必要である。日本は世界の中で あ動植物相について割と研究の進んでいる国であるが，全 体像についてまとまっているのは, 脊椎動物やチョウ・ト ンボなどの一部の昆虫類, 維管束植物などで, 大部分の昆 虫や土壌動物などは記載レベルの研究も未完成である。維
管束植物などは図鑑がいくつも出ており，日本の維管束植 物はすっかり解明が済んでいるつもりになっているが，実 状はそうではない。明らかに未記載の植物や研究の進んで おらず実体のはっきりしない植物というのがかなりあるこ とが判る。したがって，図鑑などにでている日本の植物相 のリストというのは現時点の暫定的なあのである。日本に はシダ植物・裸子植物・被子植物あわせて, 変種以上で約 7000 分類群が認識されている。この 7000 全てについて絶 滅危惧の程度を吟味できれば，良いのだが全てを一から行 うのは力量的に無理があるので, 絶滅色惧の懼れの少なそ うな種（変種）は省き，絶滅の可能性の高い種をリストアッ プしここのリストに基づいて現状調查を行った。リストに 載せる種の選定は植物の分類研究者が意見を持ち寄って調 整を行ったが，日本全体の植物について情報が少ない種や 植物の現状の情報に偏りがあり，その過程で抜け落ちたも のああった。

最初のレッドデータの候補種が選定されてからの作業も 色々な難しい問題があった。全国を少数の人間で調査する ことは無理なので, 調査は県単位で行うことになったが, 県単位でも個人の範囲では困難である。また絶滅危惧植物 の調査にはその地方の植物に精通した研究者の存在が欠か せないが，県によってはそのような地方の植物研究者がほ とんぞいない県もかなりあった。

私は長野県の調査を担当したが, 長野県には高山や湖沼 が多く, 目的の場所に到達するのも容易でないし, 湖沼な ぞでは植物にアクセスするのも容易でない。長野県には植 物に詳しい人が結構いるので, そういう方に調査に協力し て頂いたが，調查期間の 2 年間で実際に調查できた植物と 場所は限定された。

絶滅危惧の程度を評価するためには，昔から現在までの 減少率のデータが必要である。10 年 20 年前の個体数につ いてのデー夕は昔から植物を調査している年配の人の記憶 や地方植物誌の情報に頼らざるを得ない面があり, 情報と してかなり不完全である。昔あった場所全てを 2 年間の間

*信州大学理学部 
に訪れることも困難であり，現状不明の産地が多くなった。 また減少要因の特定も容易でないものあある。ダム建設や 採集など減少要因が明らかな場合ああるが突然池から消え てしまった水草もあった。植物研究者の少ない地方では, もともとそのような情報が残されていない。

このように不完全な点を内包しているが, 全国の絶滅危 惧植物についての調査データはものすごい量だった。基礎 データのコンピュータへの入力だけでもかなり大変な作業 だった。産地数・産地の個体数・減少率のデー夕を基にあ る年までの絶滅確率 (生存確率) を計算するプログラムを ある研究者が開発した。計算の基となっているデー夕に不 十分な点はあるが，日本の植物全体を対象にこのような大 がかりな試みがなされたのは，世界でも始めてのことで充 分誇りにして良いことである。昔から個体数が非常に少な く, 情報も少ない種は, ある意味では非常に絶滅の懼れの 高い種だが, このような調査から漏れる可能性があること に留意する必要がある。一例を挙げると, カイサカネラン という植物は, 中国の雑誌に記載され, 産地屯山梨と長野 の 3 個所だけで標本もほとんどなかったので, 日本で認識 している人もほとんどなく絶滅種の候補種にも載らなかっ たのだが, 最近再発見されなければ, 記録にも残らなかっ たであろう。

\section{2.レッドデータブックの有効活用}

植物版レッドデータブックを例にとりレッドデータブッ クの作成について説明したが，他のレッドデータブックで あ基本的には同様であろう。基礎となるデータに上に述べ たような問題点はあるが, レッドデータブックは公表され た範囲でのその時点での絶隇危惧生物の最新の情報と言っ て良い。レッドデータブックの有効活用について考えてみ たい。

地元の市民にとっては，自分の生活空間によ゙のような絶 滅危惧生物が生育しているか, 身近な環境を評価するのに 役立つだろう。レッドデータブックは国単位, 県単位で出 版されることが多いので, 出来れば市民自身が自分の歩く 範囲などの行動範囲のなかで, どのような絶滅危惧生物が 生育しているのかチェックしてみよう。絶滅危惧生物は人 為的な影響の少ない自然度の高い環境に生育している生物 が多い。自分の生活領域に絶滅危惧植物が複数生育してい るなら，自然環境の面でかなり質の高い空間に生活してい ると言って良い。

レッドデータブックにより行政の担当者は自分の管轄し ている地域によ゙のような絶滅危惧生物が生育していること が判り, 対策が立てやすくなる。しかしながら, レッドデー タブックのカバーしている範囲はかなり限定され, 調査漏 れの地域がかなりあるのが実状である。工場や道路建設な ごで問題になる地域から絶滅危惧生物の報告がなくても,
単なる調査漏れの可能性むあるので, 近隣の地域や類似し た環境に生育する絶隇危惧生物の有無を検討すべきである。

同様のことは環境アセスメントなどの環境評価事業に携 わっている人にも当てはまる。地方の植物誌・動物誌を調 べれば, 事業予定の地域に生息・生育する生物の概略を掴 むことが可能であろう。そのなかに出てくる生物をレッド データブックと照らし合わせれば, 事業予定地域内に生育・ 生息する可能性の高い絶滅危惧生物をリストアップし，対 策を立てることに利用することができるだろう。事業予定 地内の調査と絶滅危惧生物リストと照合し, 事業用地内で 見いだされない絶滅危惧生物に関しては，その種の生育地 や開花時期の情報などを参考に，入念な再調査をする必要 がある。

\section{3. 今後の問題点}

現時点であ作成されたレッドデータブックは非常に役に 立つものであるが，いくつもの問題点を抱えているのも事 実である。これらの点を指摘して結びとしょう。

現在出版されているレッドデータブックの中でも植物版 のレッドデータブックは非常に質の高いものだが，前にも 指摘したように，いくつかの欠陥や問題点がある。まず, 県や地域により情報の量や精度に粗密がある。これはその 地域に植物に関心のあるナチュラリストがいるかどうかに 関係している。これは学校教育の中で郷土の自然をどのよ うに教えていくかという問題に繋がるが，これは後で取り 上げたい。

全国レベルで調査を行うためには，各県単位で調査体制 を取ることが必要である。情報の少ない離島などには, 個 人のボランティアにまかせるのでなく，専門家を派遣する ことも必要になろう。実は調査を正確に行える専門家が圧 倒的に不足している。また, 地方の植物研究者の高齢化が 進んでいるのも，大きな問題となっている。数十年間かけ て蓄積された個人の情報が個人の死去とともに失われるの は社会的にも大きな損失である。

レッドデータブックの価値というのは情報の量とともに 情報の正確さが大きな比重を占めている。植物の同定の間 違いが 1 割も含まれた情報はほとんど使いものにならない。 レッドデータブックに用いられた情報はなるべく後日再検 討できるように，証拠標本を残しておくことが望ましい。 しかしながら，対象が絶滅危惧生物であるので，個体を殺 すことは望ましくない。植物なら花 1 個と葉 1 枚とか標本 としては不完全だが，個体の生存を優先すべきだろう。鳥 などは標本を得ることが困難と思われるので写真などの証 拠を残して置くことが必要だろう。今回作成された植物版 レッドデータブックでは，情報のかなりの部分が目撃情報 で証拠標本が残っていない。そのため, 同定の間違いだけ でなく，色々なトラブルやミスが生じる。例えば，植物の 
分類は固定したものでなく, 研究の進展に伴い, かなり変 化するものである。以前フクジュソウ 1 種だったものが, 現在ではフクジュソウ, ミチノクフクジュソウ, キタミフ クジュソウの 3 種に区別されている。証拠標本が残ってい ないと，昔のフクジュソウの記録がどれに相当するのか決 定するのが困難である。

レッドデータブックというのは 5 年毎くらいに更新する 必要があるが， あとになるデータベースの維持・更新を誰 がどのように行うのかも大きな問題になる。レッドデータ ブックを作成しても, 調查漏れのデータや同定の誤認・記 入ミスなどデータベースの修正が必要になる。これを個人 が本業の合間に行うのはかなり無理があり, 何らかの組織 的な対応が必要である。

レッドデータブックの作成・修正は，（可能ならば） 2 万 5 千分の 1 位のメッシュ単位の情報の調査・情報の正確

資料 我が国における絶滅のおそれのある野生生物の種数（環境省資料）

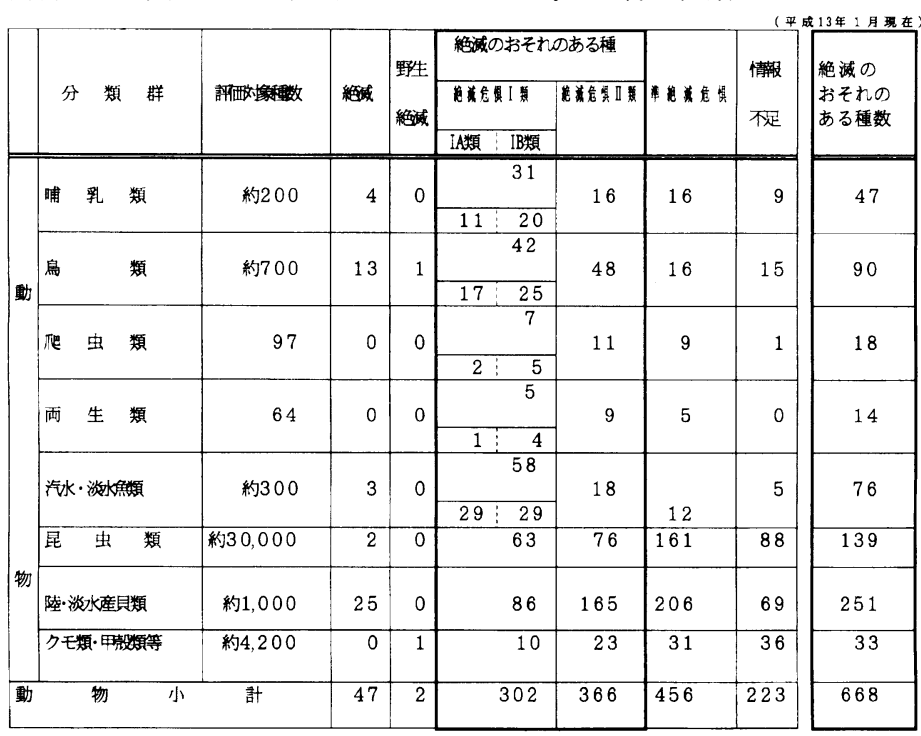

\begin{tabular}{|c|c|c|c|c|c|c|c|c|c|}
\hline \multirow{2}{*}{\multicolumn{3}{|c|}{ 維管束植物 }} & \multirow{2}{*}{ 約 7,000} & \multirow{2}{*}{20} & \multirow{2}{*}{5} & 1,044 & \multirow{2}{*}{621} & \multirow{2}{*}{145} & \multirow[b]{2}{*}{52} \\
\hline & & & & & & \begin{tabular}{|l:l}
56480 \\
\end{tabular} & & & \\
\hline 植 & \begin{tabular}{|l|l|} 
荅 \\
\end{tabular} & & 約 1,800 & 0 & 0 & 110 & 70 & 4 & 54 \\
\hline 物 & 藻 & 類 & 約 5,500 & 5 & 1 & 35 & 6 & 24 & 0 \\
\hline 等 & 地 衣 & 類 & 約 1,000 & 3 & 0 & 22 & 23 & 17 & 17 \\
\hline & 菌 & 類 & 約 16,500 & 27 & 1 & 53 & 10 & 0 & 0 \\
\hline 植 & 物 & & 計 & 55 & 7 & 1,264 & 730 & 190 & 123 \\
\hline
\end{tabular}

\begin{tabular}{|r|}
\hline 1,665 \\
\hline 180 \\
\hline 41 \\
\hline 45 \\
\hline 63 \\
\hline 1,994 \\
\hline
\end{tabular}

\begin{tabular}{|l|l|l|l|l|l|l|l|}
\hline 合 計 & 102 & 9 & 1,566 & 1,096 & 646 & 346 \\
\hline
\end{tabular}

さの認定（同定）・データの集約作業・絶滅危惧の程度の 解析などの作業が必要である。植物の場合メッシュ単位の 調査を行おうとすると，ひとつの県で 100 人程度の調査協 力者が必要であろう。調査協力者自身にもある程度の同定 能力が必要であるが, 何十万件むあるデー夕の正誤をチェッ クするのはかなり大变な作業であり, また高度の同定能力 を必要とされる。今回の植物版レッドデータブックの作成 にあたっては環境庁自身にこのような調査・研究部門が弱 体なので, 植物分類学会会員を中心に環境庁に協力した。 しかしながら，分類学研究者がある程度協力する必要性は 認めるが, 本来の自分自身の研究テーマの追究を優先すべ きだろう。いくつかの県では県立博物館の学芸員を中心に 県のレッドデータブックや植物誌などの編纂が市民を巻き 込む形で進められている。日本全体で県別のレッドデータ ブックが作成され，それをまとめる形で日本全体のレッド データブックがまとめられるのが望ましい形態かも しれない。国のレッドデータブックに準拠する形で, 県や地方のレベルのレッドデータブックが作成され ているが，国と地方のレッドデータブックの編集に 関する話し合いなどは持たれておらず，独立して作 業が進められている。データの著作権などの問題は あるが，公開できる範囲で，互いのデー夕を交換す ることが必要であろう。そのためには，情報を共有 しやすい形になるように, 調査項目・フォーマット の形式の統一, 同定根拠などについてある程度統一 しておくことが望ましい。

レッドデータブックを作成する上で最む大きな問 題のひとつは，前の段落でも触れたように，生物の 同定能力のある人物が少なく，同定能力のある人間 を育成しようとする社会的な仕組みが整備されてい ないことである。現在, 植物の分類関係は維管束植 物や藻類に関しては大学にいくつかの研究室があり, 分類学の研究者の育成がなされている。しかしなが ら, 大学の分類学の研究室の主要な研究目的は分類 学的な課題を解明することであり, 同定能力のある 学生を社会に供給することではない。生物の同定能 力のある人間に対する社会的な需要は充分あると思 われるので，そのような人間を育成する大学・博物 館などでの教育プログラムを策定する必要がある。

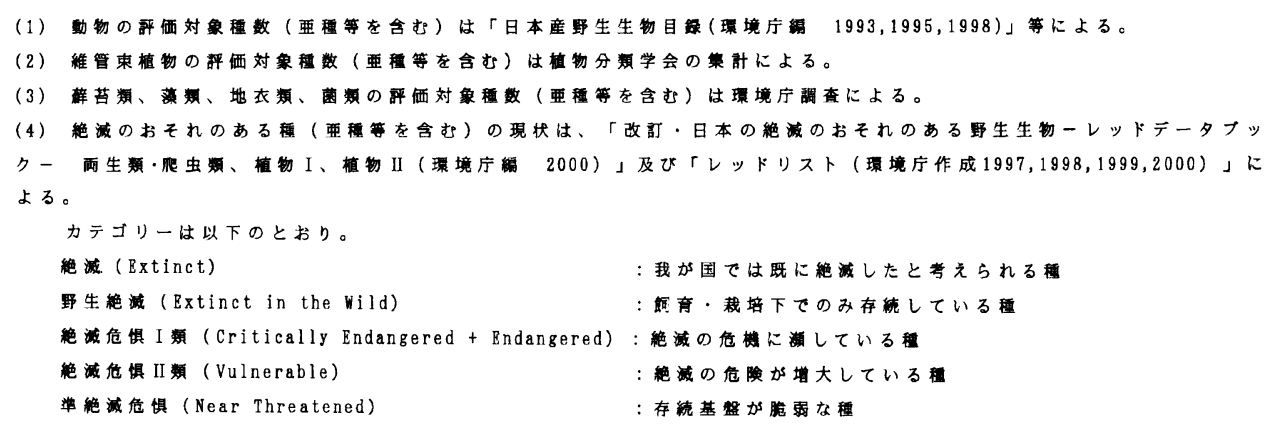

